\title{
FACTORS AFFECTING TO CUSTOMER ADOPTION OF INTERNET BANKING
}

\author{
H.A.H HETTIARACHCHI \\ Department of Commerce and Financial Management \\ University of Kelaniya, Sri Lanka \\ harshaka@kln.ac.lk
}

\begin{abstract}
This paper reports the findings of a study concerning the adoption of internet banking by investigating consumer adoption within the context of Sri Lankan banking services. The research framework was based on the extension to decomposed theory of planned behavior which mainly includes attitude (including innovation characteristics such as relative advantage, compatibility, complexity, trialability and risk), subjective norms, and perceived behavioral control to assess internet banking adoption behavior. Online questionnaire survey was conducted to gather the data and 108 complete responses were gathered from random banking customers who were internet users from Colombo and Gampaha district. Descriptive analysis was done to provide strength to the research study which showed that even though considerable people were aware about internet banking, most of them were resistance to adopt internet banking. Spearman's rank correlation was used to examine relationship of eleven hypotheses with actual internet banking usage. Results revealed that attitudinal and perceived behavioral control factors rather than social influence (subjective norms) plays a significant role in influencing adoption of internet banking. In particular relative advantage, compatibility with values, internet skills, trialability, risk, confidence of using such services (self-efficacy), and technology support found to influence the adoption of internet banking. Conclusion of the research study implied that banks have to majorly influence the internet banking adoption through 'pull strategies'.
\end{abstract}

Keywords: Internet Banking, Sri Lanka, Resistance, Adoption, Behavior, Innovation

\section{Introduction}

Banking industry in Sri Lanka plays a vital role in managing financial assets. Conventionally all the banking activities were carried out manually and always customers had to went to the branch. This has consumed lot of time as well as the cost to both customer as well as bank. Internet banking is now capturing the banking industry at a rapid phase by eliminating and 
transforming the conventional banking activities to a web based online system. Even though this enhancement of new technology, recent finding in Sri Lanka illustrates that customers were more resistance toward adopting such technology even it has more sufficient relative advantages. It was found that only less than $1 \%$ of bank customers, in general, use online banking, mobile banking, telephone banking and internet payment gateway and although ATM services are extensively used, the usage of other IT driven services such as online banking, mobile banking, internet payment gateway and telephone banking is almost insignificant (Suraweera et al, 2011).

So with this prevailing situation this research study will drive on to identify the significance of why most Sri Lankans are resistant to adopt internet banking hence these findings are useful to professionals in the banking sector, especially for developers of such information systems and the strategy makers, towards taking the banking services to a level commonly applicable in the developed world today. This study will be looking at in-depth regarding actual customer perspective on adoption or non-adoption of internet banking thus objective is to identify factors affecting to adoption of internet banking.

\section{Literature Review}

\section{Internet Banking}

Internet banking has many names such as online banking, electronic banking, e banking, virtual banking etc. In general it is a feature introduce by the bank to its customers to log into their individual registered domain account (through the given username and password) on bank website (through internet) and do almost every transaction they do by visiting the bank. Registered internet banking users can perform common banking transactions such as writing checks, paying bills, transferring funds, printing statements, and inquiring about account balances etc. Today many banks are internet only banks where no brick and mortar bank branches. Internet banking services are crucial for long term survival of the banks in the world of electronic commerce (Burnham, 1996).

\section{Importance of Internet Banking}

The main benefits of internet banking to banks are cost saving, reaching new segments of the population, efficiency, enhancement of the bank's reputation and better customer service and satisfaction (Brogdon, 1999; Jayawardhena et al, 2000).Traditional banks operating cost account for between $50 \%$ and $60 \%$ of revenues, running costs of internet banking is estimated at between $15 \%$ and $20 \%$ of revenues (Booz-Allen \& Hamilton, 1997). The cost of an 
electronic transaction is dramatically less when done online compare to at a branch (Robinson, 2000). The single most important driving force behind the implementation of full service internet banking by banks is the need to create powerful barriers to customer exiting (Sheshnoff, 2000). He argues that once a customer moves to full service internet banking, the likelihood of that customer moving to another financial institution is significantly diminished. A survey in Denmark argued that internet banking might be useful for strengthening crossselling and price differentiation (Mols, 1998). Online banking is very useful and powerful means which leads banking industry towards development, growth. It helps to enhance the competitiveness of institutions (Kamel, 2005).

From the consumer's perspective, internet banking provides a very convenient and effective approach to manage one's finances as it is easily accessible 24 hours a day, and seven days a week. Besides, the information is current. With the help of the internet, banking is no longer bound to time or geography. It has also been argued that electronic banks are more likely to change in response to customers demand (Brogdon, 1999).Customers can manage their banking affairs when they want, and they can enjoy more privacy while interacting with their bank. It has been claimed that internet banking offers the customer more benefits at lower costs (Mols, 1998).For users, convenience was the key benefit of internet banking (Dassanayake, 2003). Internet banking is extremely beneficial to customers because of the saving in costs, time and space it offers, its quick response to complaints, and its delivery of improved services, all of which benefits make easier banking (Turban, 2000).

\section{Status of Internet Banking in Sri Lanka}

As per records in central bank of Sri Lanka currently (2012) there are 24 listed commercial banks in Sri Lanka from that 12 are local banks who already have the internet banking facility except Amana bank.

But the dark side of the internet banking in Sri Lanka is, even though majority of the customers in the country were aware about e-banking facilities, most of them had not been tried those facilities by themselves. They still pay their bills, withdraw money, check balances, and deposit cheques at their bank counters much as the traditional way (Jayasiri \& Weerathunga, 2008). Although the banking professionals interviewed by the researchers themselves are not pleased with this situation, they appear to be contented with the status quo (Suraweera et al, 2011).Since now internet banking expanding its position from desktop PC to mobile phone but Sri Lankans still resistance to adopt internet banking is becoming a huge 
problem. Due to majority of Sri Lankans are not technology savvy, the banks tend to adopt a wait and see attitude (Suraweera et al, 2011).

\section{Theoretical Framework}

This research study is mainly focus on identifying the factors influencing to adoption of internet banking in Sri Lanka. The research framework for this study is based on the extension to decomposed theory of planned behavior (Tan \& Teo, 2000).

\section{Extension to Decomposed Theory of Planned Behavior}

The theory of planned behavior (TPB) is widely studied model from social psychology which was extended from the theory of reasoned action (TRA). TPB hypothesized by individual's behavioral intension (BI) to perform a behavior is jointly determined by the individual's attitude toward performing the behavior (ATB), subjective norm (SN) and perceived behavioral control (PBC). Taylor and Todd (1995) extended theory of planned behavior by decomposing the attitude component (as relative advantage, compatibility, complexity, which were mentioned in diffusion of innovation theory by Rogers, 1983) and perceived behavioral control component (as self-efficacy and facilitating conditions). Based on the above decomposed theory of planned behavior, Tan \& Teo (2000) extended it to identify the factors influencing internet banking adoption behavior on Singapore. So this research study is mainly based on this extended theory of planned behavior and it is composed with;

\section{1) Attitude}

Attitude is defined as an individual's positive and negative feelings (evaluative effect) about performing target behavior (Fishbein \& Ajzen, 1975). The different dimensions of attitudinal belief toward an innovation can be measured using the five perceived attributes (relative advantage, compatibility, complexity, trialability and observability) specifically first three attributes of an innovation (Taylor \& Todd, 1995). These attributes were originally proposed in the diffusion of innovations theory (Rogers, 1983), were applied in this framework with the exception of observability, which is defined as the degree to which the results of an innovation are visible to others (Rogers, 1983). Observability was considered irrelevant in this study because an important characteristic of doing banking is 'privacy'. Therefore, observing others using internet banking services may prove difficult unless one makes a conscious effort to do so (Tan \& Teo, 2000). 


\section{a) Relative Advantage}

Relative advantage is the degree to which an innovation provides benefits which supersede those of its precursor and may incorporate factors such as economic benefits, images, enhancement, convenience and satisfaction (Rogers, 1983). In general relative advantage of an innovation is positively related to its rate of adoption (Rogers, 1983). Likewise, as internet banking allows customers to access their banking accounts from any location, at any time of the day, it provides tremendous advantage and convenience to users. It also gives customers greater control over managing their finances, as they are able check their accounts easily. In view of the advantage that internet banking services offer, it would thus be expected that individuals who perceive internet banking as advantageous would also be likely to adopt the service (Tan \& Teo, 2000). This leads to the hypothesis: 01 (H1A).

\section{b) Compatibility}

Compatibility is the degree to which the innovation fits with the potential adopter's existing values, previous experience and current needs (Rogers, 1983). An innovation is more likely to be adopted when it is compatible with individual's job responsibilities and value system (Tornatzky \& Klein, 1982). Internet banking has been viewed as a delivery channel that is compatible with the profile of the modern day banking customer, who is likely to be computer-literate and familiar with the internet. Therefore, it is expected that the more the individual uses the internet, and the more he or she perceives the internet as compatible with his or her life style, the more likely that the individual will adopt internet banking (Tan \& Teo, 2000). Thus, the hypotheses are: 02 (H1B), 03 (H1C).

In terms of compatibility with needs of the potential adopters, internet banking can be seen as an expeditious tool that allows customers to better manage their multiple accounts. As there are more financial products and services, it is expected that individuals who may have many financial accounts and who subscribe to many banking services will be more inclined to adopt internet banking (Tan \& Teo, 2000). This leads to the following hypothesis: 04 (H1D).

\section{c) Complexity}

Compatibility is the degree to which an innovation is perceived to be difficult to understand, learn or operate (Rogers, 1983). An innovation with substantial complexity requires more technical skills and needs greater implementation and operational efforts to increase its chances of adoption. As the internet is very user friendly with its "point and click" interface, it is likely that potential customers may feel that internet banking services are less complex to 
use, and hence would be likely to use such services (Tan \& Teo, 2000). This leads to the hypothesis: 05 (H1E).

\section{d) Trialability}

Trialability is the degree to which an innovation may be experimented with on a limited basis (Rogers, 1983).Potential adopters who are allowed to experiment with an innovation will feel more comfortable with the innovation and are more likely to adopt it (Rogers, 1983). Thus, if customers are given the opportunity to try the innovation, certain fears of the unknown may be minimized. This is especially true when customers find that mistakes could be rectified, thus providing a predictable situation (Tan \& Teo, 2000). This leads to the hypothesis: 06 (H1F).

\section{e) Risk}

A common and widely recognized obstacle to electronic commerce adoption has been the lack of security and privacy over internet. Its demonstrate risk as an additional dimension in diffusion and adoption. This has led many to view internet commerce as a risky undertaking. Thus, it is expected that only individuals who perceive using internet banking as a low risk undertaking would be inclined to adopt it (Tan \& Teo, 2000). This leads to the hypothesis: 07 (H1G).

\section{2) Subjective Norms}

Subjective norms refer to the person's perception that most people who are important to him/her think he/she should or should not perform the behavior in question (Fishbein \& Ajzen, 1975). It is related to behavior because people often act based on their perception of what others think they should do. Subjective norms have been found to be more important prior to, or in the early stages of innovation implementation when users have limited direct experience from which to develop attitudes (Taylor \& Todd, 1995). Most of the consumeroriented services, the consumer-relevant groups around the individual may influence the individual' adoption. Adopter's friends, family, and colleagues/peers are groups that will potentially influence the adoption (Tan \& Teo, 2000). Although there is no basis on which to predict how each of these groups will affect adoption of internet banking, it is nonetheless expected that the influence of these groups as a whole will be significantly related to the individual's adoption internet banking (Tan \& Teo, 2000). Therefore, hypothesis: 08 (H2) warrants investigation. 


\section{3) Perceived Behavioral Control}

Perceived behavioral control refers to the factors that may impede the performance of the behavior. This definition encompasses two components.

- The first component is "self-efficacy" and is defined as an individual's self-confidence in his or her ability to perform a behavior.

- The second component is "facilitating conditions" and it reflects the availability of resources needed to engage in the behavior.

Self-efficacy predicts intentions to use a wide range of technologically advanced products. Thus, an individual confident in having the skills in using the computer and the internet is more inclined to adopt internet banking. This is because the individual is comfortable in using the innovation (Tan \& Teo, 2000). This leads to the hypothesis: 09 (H3A).

The second component, facilitating conditions refers to the easy access of technological resources and infrastructure. The government can play an intervention and leadership role in the diffusion of innovation. Potential users, in turn would view new applications such as internet banking services more favorably and hence be more likely to use them (Tan \& Teo, 2000). The above arguments lead to the hypotheses: 10 (H3B).

As supporting technological infrastructures become easily and readily available, internet commerce applications such as banking services will also become more feasible. As a result, internet users would be expected to be more inclined to adopt internet banking. This leads to hypotheses: $11(\mathrm{H} 3 \mathrm{C})$.

\section{Research Framework}

The research framework for this study is based on an extension to decomposed TPB which developed to assess internet banking adoption in Singapore by Tan \& Teo (2000). According to Taylor and Todd, intension to adopt certain technology in return is expected to affect actual adoption of such technology. Like that, intention to adopt internet banking services, in return, is expected to affect the actual adoption of internet banking (Tan \& Teo, 2000).So in this research study 'intention to adopt' is exempted from this Tan \& Teo's (2000) framework since intention obviously lead to actual behavior. Also in this research study it is mainly focused on observing the actual internet banking usage behavior rather than intention to perform actual behavior thus then it is possible to assess factors affecting to actual adoption or non-adoption of internet banking. Figure 01 show the relevant research framework use for this study which was designed based on extension to decomposed TPB. 


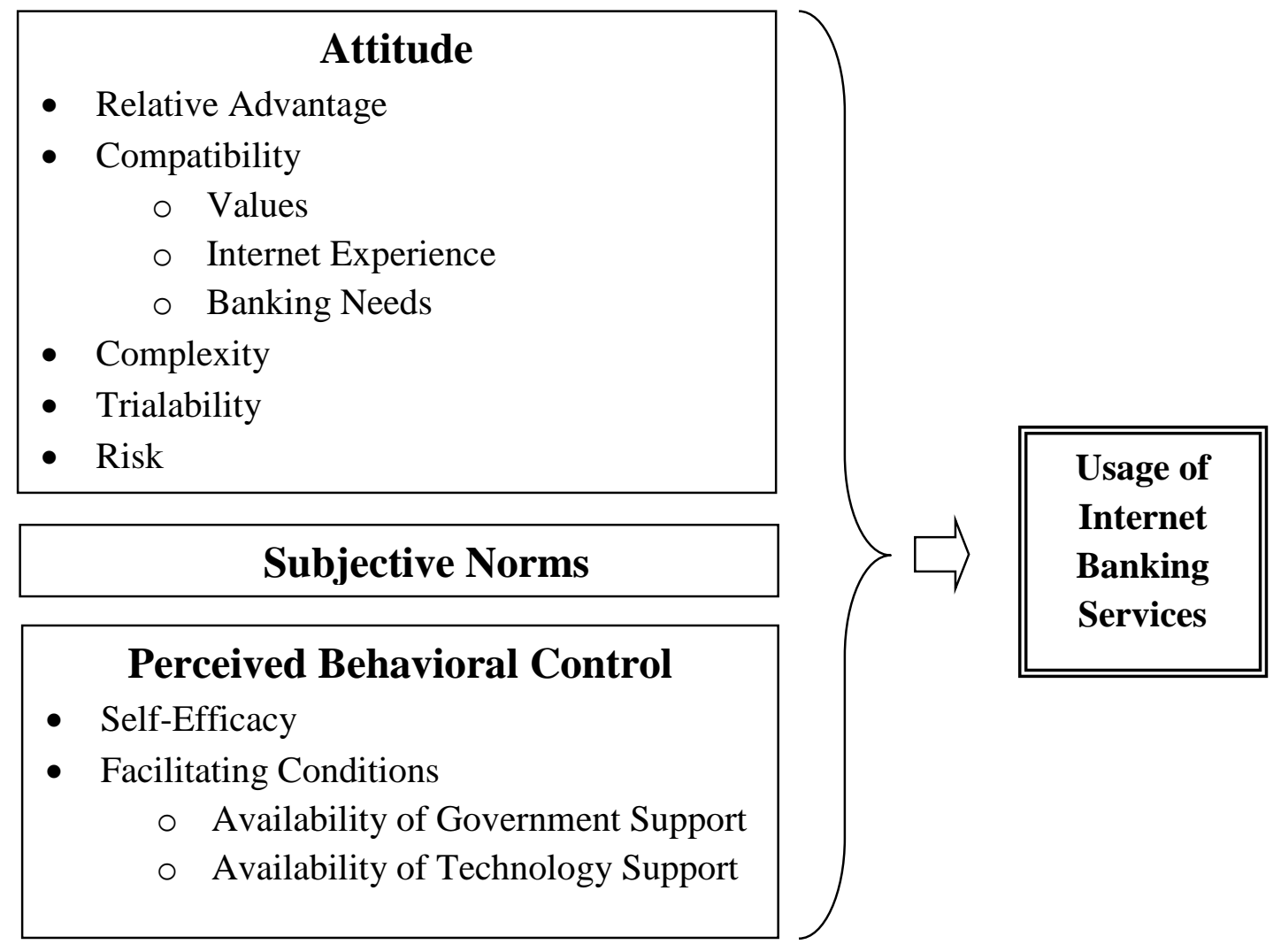

\section{Figure 01: Research Framework}

According to the above theoretical framework, following hypotheses can be constructed,

1. H1A: The greater the relative advantage of using internet banking services, the more likely that internet banking will be adopted.

2. H1B: The greater the compatibility of internet banking with one's values, the more likely that internet banking will be adopted.

3. H1C: The greater the experience with using the internet, the more likely that internet banking will be adopted.

4. H1D: The greater the use of banking products and services, the more likely that internet banking will be adopted.

5. H1E: The lower the complexity of using internet banking, the more likely that internet banking will be adopted.

6. H1F: The greater the trialability of internet banking, the more likely that internet banking will be adopted.

7. H1G: The lower the risk of using internet banking, the more likely that internet banking will be adopted.

8. H2: The beliefs associated with subjective norms are significantly related to an individual's adoption of internet banking. 
9. H3A: The greater the self-efficacy toward using internet banking, the more likely that internet banking will be adopted.

10. H3B: The greater the extent of government support for internet banking, the more likely that internet banking will be adopted.

11. H3C: The greater the extent of technological support for internet banking, the more likely that internet banking will be adopted.

\section{Research Methodology}

The main goal of this study is to identify the factors influencing adoption of internet banking from customer's point of view thus the most appropriate strategy is quantitative survey. The online questionnaire method is used because the internet is the most suitable medium through which to reach the desired sample of internet users hence the findings can only apply to internet users rather than general population (Tan \& Teo, 2000). So in this study it was justifiable to get data from internet users in order to apply Sri Lanka as a whole. Also internet users were considered because it was assumed that in order to be familiar with internet banking, respondents have at least familiar with internet and on the other hand emails users were assumed to be internet users where this research gathered data through emails. Among the provinces the highest computer awareness of $51 \%$ is reported by the western province and highest email use of $18.5 \%$ is reported from western province thus the pattern of using the internet among provinces is similar to the pattern of email use and it is important to note that the higher the use of internet higher the use of email (Media Center for National Development of Sri Lanka, 2010). Based on above statistics sample population of this study was limited to Colombo and Gampaha district banking customers, who were internet users or rather email users since most of the computer and internet savvy people live in these districts. Also in order to use internet banking, respondents should be bank customers obviously since non-banking customer doesn't have any intention of using internet banking. In order to get responses online and the link of this questionnaire was attached to email message and send it to desired individuals thus simple random sampling technique was used. 15 days were allocated to get the responses. From the 180 personalized emails sent 108 responses were collected which were complete with no missing data. So the sample size was 108 and the response rate was $60 \%$.

\section{Reliability}

Cronbach's coefficient alpha was computed to test for reliability extracting the first 20 respondents' data (table 01).As a standard mechanism it is suggested to have minimum 0.6 
Cronbach's alpha for early stages of research to assess its reliability (Nunnally, 1967) hence the constructs were deemed to have adequate reliability to continue the data analysis.

Table 01: Cronbach's Coefficient Alpha

\begin{tabular}{|c|l|c|}
\hline \multicolumn{1}{|c|}{ Factor } & \multicolumn{1}{|c|}{ Variables } & Cronbach's Alpha \\
\hline \multirow{2}{*}{ Attitude } & Relative Advantage & 0.92 \\
\cline { 2 - 3 } & Compatibility with Values & 0.83 \\
\cline { 2 - 3 } & Internet Experience & 0.89 \\
\cline { 2 - 3 } & Complexity & 0.70 \\
\cline { 2 - 3 } & Trialability & 0.95 \\
\hline \multirow{2}{*}{ Subjective Norms } & Risk & 0.89 \\
\hline \multirow{2}{*}{ Perceived Behavioral } & Subjective Norms & 0.92 \\
\hline \multirow{2}{*}{ Control } & Self-Efficacy & 0.74 \\
\cline { 2 - 3 } & Technology Support & 0.86 \\
\cline { 2 - 3 } & Government Support & 0.72 \\
\hline
\end{tabular}

\section{Findings}

In order to provide strength to the research study a descriptive analysis was conducted to identify internet banking demographic characteristics such as awareness and usage of internet banking.

\section{Internet Banking Awareness}

According to the table 02, shows that most of the respondents $(87 \%)$ were well aware of internet banking facility where as lesser respondents were not aware.

Table 02: Internet Banking Awareness

\begin{tabular}{|l|c|c|}
\hline Awareness & Count & Frequency \\
\hline YES & 94 & $87 \%$ \\
\hline NO & 14 & $13 \%$ \\
\hline
\end{tabular}

\section{Internet Banking Usage}

Even though most respondents were aware (87\%) about internet banking it seems that only around $37 \%$ of respondents were actually using internet banking (table 03 ) and it demonstrate that only $43 \%$ of respondents who aware about internet banking were actually using it, which was around half less than the awareness. So it nicely showed the objectives of this study, 
'identifying the factors influencing to adoption of internet banking' and this evidence has strengthened the objectives of this study.

Table 03: Internet Banking Usage

\begin{tabular}{|l|c|c|}
\hline Usage & Count & Frequency \\
\hline YES & 40 & $37 \%$ \\
\hline NO & 68 & $63 \%$ \\
\hline
\end{tabular}

\section{Test of Hypothesis}

11 hypotheses were formed at the beginning of the research and were tested. Spearman's rank correlation test used to measure the relationship since gathered data were in form of ordinal scale (5 point likert). All the items in operationalization were tested for correlation with actual internet banking usage. Then those correlations were used to assess the hypotheses thus relationships were accepted and rejected accordingly. All the hypotheses were tested subject to $5 \%$ significance level.

\section{Relative Advantage and Internet Banking Adoption (H1A)}

H1A: The greater the relative advantage of using internet banking services, the more likely that internet banking will be adopted can be accepted (table 04).

Table 04: Correlation with Relative Advantage

\begin{tabular}{|c|c|c|c|c|}
\hline Item & Question No. & p-value & Rho & Relationship \\
\hline RELADV 01 & 21 & 0.000176 & 0.781 & Strong Positive \\
\hline RELADV 02 & 22 & 0.046090 & 0.270 & Low Positive \\
\hline RELADV 03 & 23 & 0.000291 & 0.623 & Strong Positive \\
\hline RELADV 04 & 24 & 0.000156 & 0.785 & Strong Positive \\
\hline RELADV 05 & 25 & 0.009587 & 0.391 & Moderate Positive \\
\hline RELADV 06 & 26 & 0.000324 & 0.738 & Strong Positive \\
\hline
\end{tabular}

\section{Compatibility with Values and Internet Banking Adoption}

H1B: The greater the compatibility of internet banking with one's values, the more likely that internet banking will be adopted can be accepted (table 05). 
Table 05: Correlation with Compatibility with Values

\begin{tabular}{|c|c|c|c|c|}
\hline Item & Question No. & p-value & Rho & Relationship \\
\hline COMPAT 01 & 27 & 0.004035 & 0.382 & Moderate Positive \\
\hline COMPAT 02 & 28 & 0.036830 & 0.282 & Low Positive \\
\hline COMPAT 03 & 29 & 0.004132 & 0.352 & Moderate Positive \\
\hline
\end{tabular}

\section{Internet Experience and Internet Banking Adoption}

H1C: The greater the experience with using the internet, the more likely that internet banking will be adopted can be partially accepted only in terms of internet skills (INTSKILL) (table 06).

Table 06: Correlation with Internet Experience

\begin{tabular}{|c|c|c|c|c|}
\hline Item & Question No. & p-value & Rho & Relationship \\
\hline INTUSE 01 & 11 & 0.7727 & 0.039 & No Relationship \\
\hline INTUSE 02 & 12 & 0.9159 & -0.015 & No Relationship \\
\hline INTUSE 03 & 13 & 0.1014 & 0.223 & No Relationship \\
\hline INTUSE 04 & 14 & 0.6334 & 0.052 & No Relationship \\
\hline INTSKILL 01 & 15 & 0.0073 & 0.358 & Moderate Positive \\
\hline INTSKILL 02 & 16 & 0.0226 & 0.307 & Moderate Positive \\
\hline INTSKILL 03 & 17 & 0.0217 & 0.309 & Moderate Positive \\
\hline INTSKILL 04 & 18 & 0.0128 & 0.327 & Moderate Positive \\
\hline
\end{tabular}

\section{Banking Needs and Internet Banking Adoption}

H1D: The greater the use of banking products and services, the more likely that internet banking will be adopted can be rejected (table 07).

Table 07: Correlation with Banking Needs

\begin{tabular}{|c|c|c|c|c|}
\hline Item & Question No. & p-value & Rho & Relationship \\
\hline BNKNDS & 30 & 0.0918 & 0.229 & No Relationship \\
\hline
\end{tabular}

\section{Complexity and Internet Banking Adoption}

H1E: The lower the complexity of using internet banking, the more likely that internet banking will be adopted can be rejected (table 08). 
Table 08: Correlation with Complexity

\begin{tabular}{|c|c|c|c|c|}
\hline Item & Question No. & p-value & Rho & Relationship \\
\hline COMPLEX 01 & 33 & 0.0625 & -0.335 & No Relationship \\
\hline COMPLEX 02 & 34 & 0.3504 & -0.128 & No Relationship \\
\hline COMPLEX 03 & 35 & 0.6303 & -0.066 & No Relationship \\
\hline
\end{tabular}

Trialability and Internet Banking Adoption

H1F: The greater the trialability of internet banking, the more likely that internet banking will be adopted can be accepted (table 09).

Table 09: Correlation with Trialability

\begin{tabular}{|c|c|c|c|c|}
\hline Item & Question No. & p-value & Rho & Relationship \\
\hline TRIAL 01 & 36 & 0.000203 & 0.721 & Strong Positive \\
\hline TRIAL 02 & 37 & 0.000176 & 0.781 & Strong Positive \\
\hline
\end{tabular}

\section{Risk and Internet Banking Adoption}

H1G: The lower the risk of using internet banking, the more likely that internet banking will be adopted can be accepted (table 10).

Table 10: Correlation with Risk

\begin{tabular}{|c|c|c|c|c|}
\hline Item & Question No. & p-value & Rho & Relationship \\
\hline RISK 01 & 38 & 0.000669 & -0.651 & Strong Negative \\
\hline RISK 02 & 39 & 0.007501 & -0.357 & Moderate Negative \\
\hline RISK 03 & 40 & 0.000236 & -0.777 & Strong Negative \\
\hline
\end{tabular}

\section{Subjective Norms and Internet Banking Adoption}

H2: The beliefs associated with subjective norms are significantly related to adoption of internet banking can be rejected (table 11).

Table 11: Correlation with Subjective Norms

\begin{tabular}{|c|c|c|c|c|}
\hline Item & Question No. & p-value & Rho & Relationship \\
\hline SNORM 01 & 41 & 0.5557 & -0.081 & No Relationship \\
\hline SNORM 02 & 42 & 0.1667 & -0.189 & No Relationship \\
\hline SNORM 03 & 43 & 0.4057 & -0.114 & No Relationship \\
\hline
\end{tabular}


Self-efficacy and Internet Banking Adoption

H3A: The greater the self-efficacy toward using internet banking, the more likely that internet banking will be adopted can be accepted (table 12).

Table 12: Correlation with Self-Efficacy

\begin{tabular}{|c|c|c|c|c|}
\hline Item & Question No. & p-value & Rho & Relationship \\
\hline SELFEFF 01 & 44 & 0.001220 & 0.425 & Moderate Positive \\
\hline SELFEFF 02 & 45 & 0.000971 & 0.501 & Moderate Positive \\
\hline SELFEFF 03 & 46 & 0.008310 & 0.212 & Low Positive \\
\hline SELFEFF 04 & 47 & 0.000728 & 0.691 & Strong Positive \\
\hline SELFEFF 05 & 48 & 0.001500 & 0.326 & Moderate Positive \\
\hline
\end{tabular}

\section{Government Support and Internet Banking Adoption}

H3B: The greater the extent of government support for internet banking, the more likely that internet banking will be adopted can be rejected (table 13).

Table 13: Correlation with Government Support

\begin{tabular}{|c|c|c|c|c|}
\hline Item & Question No. & p-value & Rho & Relationship \\
\hline GOVSUPP 01 & 49 & 0.9926 & -0.0013 & No Relationship \\
\hline GOVSUPP 02 & 50 & 0.1540 & -0.1948 & No Relationship \\
\hline GOVSUPP 03 & 51 & 0.3795 & -0.1208 & No Relationship \\
\hline
\end{tabular}

\section{Technology Support and Internet Banking Adoption}

H3C: The greater the extent of technological support for internet banking, the more likely that internet banking will be adopted can be accepted (Table 14).

Table 14: Correlation with Technology Support

\begin{tabular}{|c|c|c|c|c|}
\hline Item & Question No. & p-value & Rho & Relationship \\
\hline TECHSUPP 01 & 52 & 0.000297 & 0.677 & Strong Positive \\
\hline TECHSUPP 02 & 53 & 0.006999 & 0.353 & Moderate Positive \\
\hline TECHSUPP 03 & 54 & 0.021028 & 0.172 & Low Positive \\
\hline
\end{tabular}




\section{Discussion}

The results from this study showed that usage of internet banking has relationships with some attitudinal factors, some perceived behavioral control factors, and not by subjective norms. There was relatively strong positive relationship between relative advantage of using internet banking services and its adoption except low positive correlation of greater control over finances, and moderate positive correlation of ability to manage finances more effectively. Highest preference for e-banking is the convenience to its customers and most popular ebanking facility is to view balance and in addition to that significant customers used to pay utility bills and relatively to view information such as interest rates, exchange rates, and bank details, etc. (Jayasiri \& Weerathunga, 2008). So the support for relative advantage was expected since past literature showed significant and positive influence on the adoption of new innovations. Ultimately more the convenience and less the effort people tend to adopt internet banking.

There was relatively moderate positive relationship between compatibility of internet banking with one's values and its adoption, except low positive correlation of ability to fits well with the way like to manage finances. It viewed that the perceived compatibility of an innovation has a positive influence on the adoption of the innovation. In other words, even internet users who feel that using internet banking is compatible with their values about living and working were more inclined to adopt such services. Most of the e-banking customers are once a month visitors to the bank (Jayasiri \& Weerathunga, 2008).

There was relatively moderate positive relationship between internet skills and internet banking adoption. No significant correlation seems to be among internet use constructs and adoption. The support for internet experience (skills) is consistent with Rogers' suggestion that compatibility of an innovation with a previously introduced idea can influence the adoption of the innovation. Further prior experience (skills) with product class (e.g. the internet) may lead to greater acceptability of new products (e.g. internet banking), hence increasing the likelihood that they will be adopted. In the context of adopting internet banking, an individual will thus be more inclined to adopt such a service if he or she has had enough experience (skill) with its supporting technology: the internet.

There was no significant relationship between use of number of banking products and services and internet banking adoption. Possible reason might be, not enough was done to localize the list of banking products provided for respondents to choose from. As well as 
usage of single or multiple banking products, same the perception for internet banking would be.

There was no significant relationship between complexity of using internet banking and its adoption. It can be justified since one possible reason might be internet banking is not a hard technical concept to Sri Lanka and it is more than decade its being in Sri Lanka even though most banks adopted recently and also greater internet skills has eliminate this complexity as well. Also perceived complexity of using an innovation begins to play a more instrumental role only after one has started hands on trials and/or use of the technology. As a result, their perceived complexity of using such services may not be significant in influencing them to adoption of internet banking.

There was relatively strong positive relationship between trialability of internet banking and its adoption. Possible reasons might be, increase in on-hand experience will mitigate the negative perception and will aware about the benefits of internet banking.

There was relatively strong negative relationship between the risk of using internet banking and its adoption except moderate positive correlation of information concerning individual's internet banking transactions will be known to others. Since internet banking involve with money, people are more afraid to use because there are lot of frauds heard all over the world so they don't want to lose their money even it is easy way.

There was no significant relationship found between subjective norms and internet banking adoption thus opinions of friends, family and other relevant groups were found to have no significant relationship with the adoption of internet banking. It emphasized that the opinions of such groups were not important with an innovation such as internet banking. Possible reasons are availability of information about internet banking online may reduce the need for users to seek out the opinions of those groups. Even relevant information is readily available from banks, thereby reducing the reliance of potential adopters on their friends, family, or colleagues for information about these services. Alternatively the fact that internet banking in Sri Lanka is relatively new trend may mean that internet user related consumer relevant groups have yet try them out. As a result, they are unable to provide the necessary information and give knowledgeable recommendations. This result is in a counter argument to the results found that subjective norms to be important in affecting adoption in the early stages of introducing an innovation, when users have only limited direct experience from which to develop attitudes. 
From the three perceived behavioral control factors, government support could not be included as a factor due to no significant relationship. Self-efficacy was found to be an influential factor and technology support indeed.

There was a relatively significant positive relationship between the self-efficacy toward using internet banking and its adoption except low positive correlation of confident of using internet banking even never used such a system before. There is a possibility of adopting if an individual sees how the system works which may increase the adoption rate and if supporting techniques are available it is likely to be adopted.

There was no significant relationship between government support for internet banking and its adoption. Possible reasons for this would include differences in how government is viewed in the Sri Lanka and may also include how government policy relates to online security and e-commerce in Sri Lanka. While government support is found to be less important in Sri Lanka, such a government's role in encouraging innovation adoption may be less salient due to the greater role of private sector.

There was a relatively significant strong positive relationship between technological support for internet banking its adoption. One possible explanation for this could be that most internet banking users expect the necessary technology support required for conducting banking transactions on the internet and expect that to readily available to anyone who is interested in using the internet banking. As a result, internet banking users may tend to take this availability for granted, hence the technology support as an influencing factor in the adoption of internet banking.

\section{Implications \& Recommendations}

The implications of these findings and conclusions were that banks need to play a leading role in influencing the perception, and there by the attitude and behavior of current and potential internet banking users. The outcome of this study has practical implication and recommendation for banks.

Awareness of internet banking services is essential in early adoption stages. Effective presentations using all forms of media advertising such as leaflets, brochures, web pages, etc., will be useful to introduce the services to a wider audience and educate potential customers about benefits of internet banking. To access more potential adopters, information about internet banking should be provided by bank teller and bank assistants at branches. The information should include references to 'time saving', 'convenience' at anywhere any time, 
'low cost', and 'information availability'. In addition, banks should design their web sites as effective delivery channels and offer information beyond banking services. It is essential to provide a well-designed and user-friendly website to attract potential adopters' attention. The customer should not be required to expand a lot of effort or time, or undergo too great a change in behavior, to adopt internet banking services. Information and instructions on the web should be provided in both English and Sinhala in order to make the adopter comfortable. Wide publicity underscoring the benefits and ease of use by demonstrating internet banking services should be provided. This could be implemented by providing personal computers at bank branches accompanied by good documentation and bank assistance. Regular surveying of customers' responses and opinions of the services should be conducted to ensure continuous improvement.

Reliability of access when needed is one of the key encouragement factors. Although this 'reliability' partly depends on customers networks, which were excluded from the study, internet banks can enhance accessibility by co-operating with ISP (internet service providers) to provide good quality internet access. Bank should also separate internal and external uses and give priority to external uses. While reliability is a key element from a customer's perspective, so is the security system. It must be enhanced continuously to guarantee integrity of online transactions as this will build customer confidence. Security provisions should be posted on banks web sites clearly and understandably to create customer confidence and improve the trustworthiness reputation of banks. Security information should be provided in non-technical terms, and be accompanied by standard security statements. The perception of quality service will increase the banks image for good services, accuracy and effectiveness. Failure of execution not only causes dissatisfaction and uncertainty to customers but also makes the whole internet banking process more complex and less comprehensible.

Bank should develop internet diffusion strategies by adopting 'Pull' strategies. Increased diffusion will increase the number of internet banking adopters since they are likely to come from the internet population. Furthermore, support from the government and the industry regulator will positively affect internet banking services by increasing the confidence of the adopters. Effective co-operation among banks has to be developed. The value of internet banking is increased by linking one activity with other both within banks and with outside suppliers, channels and customers. Furthermore, internet banks should collaborate with ISPs because it will enable banks to better control quality of services as well as enhance adopters' 
accessibility. In addition, a high quality internet infrastructure should be provided since it is one of the primary requirements for internet usage.

Support from the government and industry regulator should be effective to increase the growth of internet banking services. The Sri Lankan government should be encouraged to initiate suitable steps to remove legal and regulatory barriers to e-commerce in general and internet banking in particular. In addition to lobbying the Sri Lankan government, banks should also proactively participate in improving internet services in order to increase online banking. For example, electronic laws should be promoted by the banks in order to reduce customers' perceptions of risks. Current co-operation has been for commercial purposes, rather than for mutual benefits of the industry. Customer-targeting strategies internet banks should focus on people with high purchasing power as the first priority and attempt to shift them online. This requires extensive analyses of customers' needs and the provision of customized services that are of value to them.

\section{References}

Ajzen, I. (1985). From Intentions to Actions: A Theory of Planned Behavior, " in Action Control: From Cognition to Behavior. New York: Springer-Verlag.

Ajzen, I., \& Fishbein, M. (1980). Understanding attitudes and Predicting Behavior. Englewood Cliff, New Jersey: Prentice Hall.

Booz-Allen, \& Hamilton. (1997). Booz-Allen's Worldwide Survey Revealed a Huge Perception Gap Between Japanese and American/European Banks Regarding Internet Banking.

Brogdon, C. (1999). Banking and The Internet:Past, Present, Possibilities. http://www.db.stanford.edu/pub/gio/CSS991/banking.html.

Burnham, B. (1996). The Internet's Impact on Retail Banking. Booz-Allen Hamilton Third Quarter.

Dassanayake, D. D. (2003). Critical factors influencing the selection and continued usage of internet banking in Sri Lanka.

Fishbein, M., \& Ajzen, I. (1975). Belief, Attitude, Intention and Behavior: An Introduction to Theory and Research. Addison-Wesley.

Jayasiri, N. K., \& Weerathunga, W. (2008). Popularity of e-banking in Sri Lanka.

Jayawardhena, C., \& Foley, C. (2000). Changes in the Banking sector - The case of Internet banking in UK. Electronic Networking Application and Ploicy Vol.10, p.19-30. 
Kamel, S. (2005). The use of information technology to transform the banking sector in developing nations. Journal of Information Technology for Development, 11(4), pp. 305-312.

Media Center for National Development of Sri Lanka. (2010). COMPUTER LITERACY AMONG SRI LANKANS IS IN THE ASCENSION. Retrieved from http://www.development.lk/news.php?news=620

Mols, K. (1998). The Behavior Consequences of PC banking. International Journal of Bankmarketing, Vol.16, No.5 , 195-201.

Nunnally, J. C. (1967). Psychometric Theory. New York: McGraw-Hil.

Robinson, T. (2000). Internet Banking - Still not a perfect marriage. Information week, Vol.17 No.4, 104-106.

Rogers, E. (1983). Diffusion of Innovations . Newyork: Free press.

Sheshnoff, A. (2000). Internet Banking - An update from the frontlines. ABA Banking Journal, Vol.92, No.1, 51-55.

Suraweera, T., Kahingala, S., Batepola, A., Punchihewa, M., Senevirathna, K., \& Kahandawaarachchi, C. (2011). IT Driven Banking Services in Sri Lanka: Customer Acceptance and Service Quality.

Tan, M., \& Teo, T. (2000). Factors influencing the adoption of Internet Banking. Journal of the Association for Information System, Vol 1.

Taylor, S., \& Todd, P. (1995). Assessing IT Usage: The Role of Prior Experiences. MIS Quarterly (19:3), 561-570.

Taylor, S., \& Todd, P. (1995). Understanding Information Technology Usage: A Test of Competing Models. Information Systems Research (6:2).

Tornatzky, L., \& Klein, K. (1982). Innovation charateristics and innovation adoption implementation: a meta-analysis of findings. Engineering Management.

Turban, E. (2000). Electronic Commerce: A manegerial perspective. Pretence Hall International Inc. 